$$
\begin{gathered}
\text { 담낭 절제술로 우연히 진단된 담낭 암의 특징 } \\
\text { 이화여자대학교 의과대학 내과학교실, 약리학교실* } \\
\text { 김영선 - 이선영 - 이경은 }
\end{gathered}
$$

$=$ Abstract $=$

\title{
Characteristics of Unexpected Gallbladder Cancer Diagnosed by Cholecystectomy
}

\author{
Young Sun Kim - Sun Young Yi $\cdot$ Kyung Eun Lee* \\ Department of Internal Medicine and Pharmacology,* Ewha Womans University, College of Medicine
}

Objectives : Unexpected carcinoma of gallbaldder(GB) can be found in 1-2\% of specimens after surgery of benign biliary disease. This study was designed to investigate the clinicopathological and radiological characteristics of unexpected GB cancer presumed benign biliary disease and compare with originally diagnosed GB cancer.

Methods : The medical records of nineteen patients ( 5 males and 14 females, mean age : $64 \pm 9$ years) with unexpected GB cancer diagnosed postoperatively(Group $1:$ cholecystitis, 12 cases ; GB empyema, 4 cases ; cholecystitis with bile duct stone, 3 cases) and thirty seven patients (12 males and 25 females, mean age : $68 \pm 11$ years) with originally diagnosed GB cancer(Group 2) were retrospectively reviewed at Ewha Womans university Mokdong hospital from October, 1993 to March, 1999.

Results : Clinical findings including right upper quadrant pain, fever, and chilling were predominant in group 1 and general weakness, anorexia, and weight loss were predominant in group 2. Ultrasonographic findings of the group 1 were not typical to detect GB cancer. Diffuse thickened GB wall showed $47.3 \%$ and the gallstone showed $89.5 \%$ in group 1 . The mass or thickened GB wall irregularly revealed in all and gallstone showed in 50\% of group 2 . The TMN stage of group 1 revealed earlier stage than group 2. The curative resection was performed in $84.2 \%$ and $10 \%$ in group 1 and 2 , respectively.

Conclusion : The stage of unexpected GB cancer revealed relatively early stage and the curative resection rate was higher than originally diagnosed GB cancer. Therefore, the careful and detail intraoperative histologic examination of considered in patient with clinical features of benign biliary disease to detect early and improve prognosis in the patients of GB cancer.

KEY WORDS : Unexpected gallbladder cancer · Cholecystectomy.

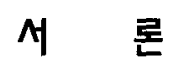

원발성 담낭 암은 담도계의 악성 종양 중 가장 흔한
질환으로 모든 소화기계의 암 중 2 4\%를 차지하는 악 성종양이달. 담낭 암의 유병률은 부검과 수술을 통한 연구 결과 $0.55 \%$ 에서 $1.91 \%$ 로 보고되며 50 대에서 60 
대의 고령에 호발한다. 다른 답낭 질환과 마찬가지고 여 성에서 2 3배 정도 발생이 높달. 발생 원인은 아직 정확히 규명되지는 않았으나. 지역적 인총적 유병율의 차이를 고려한 유전적 소인과 식생환 습관, 비만, 여성 호르몬, 그리고 발암 물질 둥이다. 또한 담석이 담낭 암 환자의 70 90\%에서 동반되기 때문에 담낭 석과 만성 담낭염은 담낭 암의 위험인자로 생각된달. 원발성 담 낭 암의 임상 중상은 매우 다양하여, 다른 양성 간 담도 질환과의 구분이 어렵다. 그래서 조기진단이 드물고 초 기에 주변 장기로 전이가 잘 되어 진단 시 이미 전이된 경우가 혼하여 예후가 매우 불량하다렉. 그러나 양성 간 담도계 질환의 수술로 우연히 진단된 담낭 암은 비 교적 조기 발견되는 경우가 많아 예후가 비교적 양호한 것으로"일려려 있지만 이에 대한 국내 고찰은 매우 적 다. 본 연구는 양성 담도질환의 담낭절제술로 진단된 담 낭 암 환자둘의 임상적 특징과 방사선학적, 그리고 병리 학적 특성을 분석하여 양성 질환이라 하더라노 의심해 봐야 할 퉇징이 있는 지의 여부폴 조사하였고 처음부터 담낭 암으로 진단한 경우와 여러 입상득징올 비교 분석 하였다.

\section{연구 대상 및 방법}

\section{1. 연구대상}

1993년 10월부터 1999년 3월까지 이화여자대학교 부속 녹동병원에 입원하여 담낭 암으로 진단한 56 예를 대상으로 하였다. 대상 환지의 평뉸 연령은 $60 \pm 10$ 세였 고 남자가 17 명, 여자가 39 명이었다.

\section{2. 연구방법}

대상 화자 충에서 양성 담노실환의 담낭절제술 충 또 는 수순 후 병리조식 소젼으로 남낭 암올 진단한 군운 1 군으로, 복부 초옴피 검사 또는 전산화 난충촬영 둥의 방사선학적 소젼과 조직녕리 소건을 통해 담낭 암으로 진단한 군운 $2^{2}$ 으로 분류하였다. 제 1 곤에서 수술 전 진단은 급성 담낭염이 12 에, 담낭 농양이 4 예, 담도 결 석을 낭반한 남낭엽이 3예였다. 눋 곤의 읶상 충상파 신 체검진 소겸, 검사신 소견, 방사선학적 소견, 담낭 암의 병기, 수술 소견, 그리고 조직병리학적 소견을 의무기폭 분석올 퉁해 후향적으로 본석하였다. 담낭 암의 병기는 TNM 분류 6에 따라 결정하였다. 통계적 분석은 SPSS
WIN 10.0표로그램운 이용하여 Student t-test와 chisquare test를 실시하였고 $p$ 값이 0.05 이하일 때 유의하 다고 파정하였다.

\section{결 과}

\section{1. 대상 환자의 맥성}

제 1 군의 환자는 총 19 명으로 평균 연령은 $64 \pm 9$ 세였 으며, 난자가 5명, 여자가 14 명이였다. 제 2 군은 총 37 명으로 평균연령은 $68 \pm 11$ 세였고 남자가 12 명, 여자가 25명으로 평균 연령 및 낞녀 비는 양 곤 간에 통계적으 로 유의한 차이가 없었다. 중상이 시작된 시기부터 네원 까지 평균 이병기간은 제 1 군이 $26 \pm 111$ 일로 1 일에서 1 년의 분포룰 보였고 12 예(63.2\%)에서 2주 이내의 기 간을 보였다. 제 2 군은 $77 \pm 100$ 일로 5 일에서 1 년의 분 포롤 보였고 6예(16.7\%)에서 2주 이내의 기간울 보여 양성 담노실환의 수술로 진단된 군에서 이병기간이 통

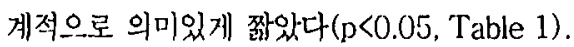

\section{2.-임상 소견}

입상충상은 체 1 군의 경우 우상복부 동봉이 17에(89. $5 \%$, 오항이 12 예(63.2\%), 발열이 8예 (42.1\%)로 염 중성 질환의 양상이 두드러졌고, 제 2군의 경우는 전신 쇠약감이 20예(55.6\%), 상복부 몽중이 20예 (55.6\%), 식욕부진이 19 예 $(52.7 \%)$, 소양감이 18 예(50.0\%), 체 중갑소가 15예(40.5\%)로 반성 소모성 질환의 중상이 우세하였다.

신체검진 소견에서 제 1 곤은 우상복부 압뿡이 17 예 (89.5\%), Murphy's sign이 11예(57.9\%)가 관찬되었 고, 체 2 눈은 복부 종괴가 축진뒤! 예가 19예 (51.4\%), 항 단이 관찰된 예가 18 예 $(48.6 \%)$ 조 유의한 차이롤 보였다 (p<0.05, Table 2).

Table 1. Comparison of clinical characteristics of patients between Group 1 and Group 2

\begin{tabular}{lcc}
\hline & Group 1 & Group 2 \\
\hline No. of cases & 19 & 37 \\
Sex (M : F) & $5: 14$ & $12: 25$ \\
Mean age (years) & $64 ! 9$ & $68 \pm 11$ \\
Duration of symptom(days) & $20+111$ & $77 \pm 100^{*}$ \\
\hline : $p<0.05$ & &
\end{tabular}

\section{dCollection @ ewha}


Table 2. Comparison of clinical symptoms and physical Findings between Group 1 and Group 2

\begin{tabular}{lcc}
\multicolumn{3}{c}{ cal Findings between Group 1 and Group 2 } \\
\hline Symptoms & Group 1(\%) & Group 2(\%) \\
Right upper quadrant pain & $17(89.5)^{*}$ & $3(8.1)$ \\
Diffuse abdominal pain & $2(10.5)$ & $20(54.1)^{*}$ \\
Chilling & $12(63.2)^{*}$ & $3(8.1)$ \\
Fever & $8(42.1)^{*}$ & $1(2.7)$ \\
General weakness & $1(5.3)$ & $20(54.1)^{*}$ \\
Anorexia & $1(5.3)$ & $19(51.4)^{*}$ \\
Pruritus & $0(0)$ & $18(48.6)^{*}$ \\
Weight loss & $2(10.5)$ & $15(40.5)^{*}$ \\
Nausea & $1(5.3)$ & $14(37.8)^{*}$ \\
Physical findings & & \\
Right upper quadrant & $17(89.5)^{*}$ & $14(37.8)$ \\
and epigastric tenderness & & \\
Murphy's sign & $11(57.9)^{*}$ & $2(54.1)$ \\
Jaundice & $5(26.3)$ & $18(48.6)^{*}$ \\
Paipable abdominal mass & $0(0)$ & $19(51.4)^{*}$ \\
\hline *: p<0.05 & &
\end{tabular}

Table 3. Comparison of laboratory findings between Group 1 and Group 2

\begin{tabular}{lcc}
\hline Variables & Group 1 & Group 2 \\
\hline Hemoglobin $(\mathrm{g} / \mathrm{dL})$ & $11.3 \pm 1.3$ & $11.1 \pm 1.7$ \\
Hematocrite $(\%)$ & $33.5 \pm 4.3$ & $32.5 \pm 4.9$ \\
WBC $(\times 103 / \mathrm{uL})$ & $12756 \pm 2500^{*}$ & $7333 \pm 3615$ \\
Platelet $\left(\times 10^{3} / \mathrm{uL}\right)$ & $248 \pm 61$ & $270 \pm 75$ \\
Aspartate & $143 \pm 115^{*}$ & $111 \pm 105$ \\
$\begin{array}{l}\text { aminotrasferase }(\mathrm{IU} / \mathrm{L}) \\
\text { Alanine }\end{array}$ & $119 \pm 105$ & $109 \pm 88$ \\
$\begin{array}{l}\text { aminotrasferase }(\mathrm{IU} / \mathrm{L}) \\
\text { Alkaline } \\
\text { phosphatase }(\mathrm{IU} / \mathrm{L})\end{array}$ & $285 \pm 207$ & $617 \pm 500^{*}$ \\
r-glutamyl & $278 \pm 220$ & $387 \pm 355$ \\
transferase $(\mathrm{IU} / \mathrm{L})$ & & \\
Total bilirubin $(\mathrm{mg} / \mathrm{dL})$ & $2.9 \pm 4.7$ & $9.0 \pm 4.8^{*}$ \\
\hline$*: p<0.05$ & &
\end{tabular}

\section{3. 검사실 소견}

검사실 소견에서 제 1 군은 백혈구수와 AST가, 제 2 군 은 Alkaline phosphatase, Total bilirubin이 유의하게 증가된 소견을 보였다( $p<0.05$, Table 3).

\section{4. 복부초옴파 소견}

제 1 군의 복부초음파검사에서 담낭 벽의 평균 두께는 $4.8 \pm 2.9 \mathrm{~mm}$ 였고, 담낭 벽의 두께가 $4 \mathrm{~mm}$ 이상 비후를 보인 경우는 9예(47.3\%)로 모두 미만성 벽비후형(di-
Table 4. Comparison of abdominal ultrasonographic findings between Group 1 and Group 2

\begin{tabular}{lcc}
\hline Ultrasonographic findings & $\begin{array}{c}\text { Group 1 } \\
\text { (19cases) }\end{array}$ & $\begin{array}{c}\text { Group 2 } \\
\text { (20cases) }\end{array}$ \\
\hline GB wall & 9 & 1 \\
Diffuse thickened wall type & 6 & 0 \\
Regular & 3 & 1 \\
Irregular & 0 & 1 \\
Focal thickened wall type & 0 & $12^{*}$ \\
Massive type & 0 & 4 \\
Polypoid type & $17^{*}$ & 10 \\
GB stone & 2 & $18^{*}$ \\
Lymphadenopathy & 3 & $16^{*}$ \\
Bile duct dilatation & 0 & 2 \\
Ascites & & \\
\hline * : p<0.05 & &
\end{tabular}

ffuse thickened wall type) 소견을 보였다. 미만성으로 담낭 벽의 비후를 보인 9 예 중에서 6 예는 규칙적이었고 3 예는 불규칙적이었다. 담낭결석은 17 예(89.5\%) 에서 동 반되었고 14예 $(74.7 \%)$ 에서 담낭 찌꺼기가 관찰되었으 며, 담도 확장이 3예 (15.8\%), 림프절종대가 2예(10.5) 크기 $2 \mathrm{~mm}$ 의 담낭 용중이 1 예 $(5.3 \%)$ 에서 관찰되었다. 제 2 군의 20 예에서 초음파를 시행하였고 담낭 벽의 비 후소견은 종괴형 (massive type)이 12예, 폴립형 (polypoid type)이 4예, 벽비후형(thickened wall type) 2예 였다. 담낭 결석은 10 예 $(50 \%)$ 에서 관찰되었고, 림프절 종대는 18 예, 담도확장 소견은 16 예, 간전이는 16 예, 복 수는 2예에서 동반되었다.

담낭 벽의 비후형태는 1 군에서 미만성 벽비후가, 2 군 은 종괴형이 많았고, 담낭결석의 동반은 1 군에서, 림프절 종대와 담도확장 소견은 2 군에서 우세하여 양 군 간에 유의한 차이를 보였다( $p<0.05$, Table 4$)$.

\section{5. 담낭 암의 병기}

제 1군에서는 I 기 2예(10.5\%), II기 4예(21.1\%) III 기 10 예 $(52.6 \%), \mathrm{IVb} 3$ 예 $(5.3 \%)$ 였고 제 2 군의 경우는 III기 3예(8.1\%), IVa 12예(32.4\%), IVb 22예(59.5\%) 로 1 군에 비해 진행된 병기를 보였다( $\mathrm{p}<0.05$, Table 5).

\section{6. 수술조건}

제 1 군의 환자 중 3 에는 복강경 담낭절제 후 육안적 으로 담낭 암이 의심되는 소견이 있어 바로 개복술로 전 환하였고 다른 3 예에서 복강경 수술 종로 후 조식병리

\section{dCollection @ ewha}


Table 5. Comparison of TNM stage between Group 1 and Group 2

\begin{tabular}{ccc}
\hline Stage & Group 1(\%) & Group 2(\%) \\
\hline 1 & $2(10.5)$ & $0(0)$ \\
II & $4(21.1)$ & $0(0)$ \\
III & $10(52.6)^{*}$ & $3(8.1)$ \\
IVa & $0(0)$ & $12(32.4)^{*}$ \\
IVb & $3(15.8)$ & $22(59.5)^{*}$ \\
\hline$*: 0<0.05$ & &
\end{tabular}

Table 6. Comparison of type of operation between Group 1 and Group 2

\begin{tabular}{|c|c|c|}
\hline Type of operation & Group 1 & Group 2 \\
\hline Curative operation & $16^{*}$ & 2 \\
\hline $\begin{array}{l}\text { Cholecystectomy, hepatic bed } \\
\text { excision and reglonal lymph } \\
\text { node dissection }\end{array}$ & 10 & 1 \\
\hline $\begin{array}{l}\text { Cholecystectomy, rlght hepatic } \\
\text { lobectomy and regional lymph } \\
\text { node dissection }\end{array}$ & 4 & 1 \\
\hline Cholecystectomy only & 2 & 0 \\
\hline Palliative operation & 3 & $18^{*}$ \\
\hline $\begin{array}{l}\text { Cholecystectomy } \\
\text { and T-tube choledochostomy }\end{array}$ & 2 & 4 \\
\hline $\begin{array}{l}\text { Cholecystectomy } \\
\text { and choledochojejunostomy }\end{array}$ & $T$ & 9 \\
\hline Laparotomy and biopsy only & 0 & 5 \\
\hline
\end{tabular}

$*: p \leq 0.05$

소견에서 담낭 암으보 진단되었다. 나더시 13예는 개복 술을 실시하였고 이충 11 에는 적제된 남낭의 욱안적 소 견에서 담낭 암이 의심되는 부분이 있어 조식병리검사 확인 후 곤치적 접체순울 시행하였고 나머지 2예에서는 수술 종포 후 조식병리소견에서 남낭 암으로 진난되었 다. 수술 후 조지병리 소견으로 진단된 답낭 암 5에 충

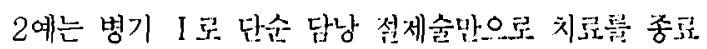
하였고 2예는 벙기 II 로 2차 개복술올 시행하였으며, 1 예는 III 병기로. 2차 수순을 거부하여 더 이상의 치로가 불가능하였다. 근치적 전체순을 시행한 16 에 $(84.2 \%)$ 중 단순 담낭집세순만 시행한. 겅우가 2예(14.3\%), 담낭 절제술, 린포전 곽칭술, 느리고 선상간 전세숩은 시행한 경우가 10에 (62.5\%), 닫낭전제술, 간우엽 전세순 및 립 프절 곽청술울 시행한 경우가 4예(25.0\%) 였다. 고식적 절제술울 시행한 경우는 3예(15.8\%) 로 담낭절체술 빛 $T$-관 배액술, 총담도강상 문합술올 시행하였다.

제 2 춘의 환자 충 20 예에서 수술을 시행하였고. 근치 적 절제술을 시힝한 경우는 2에(10\%)로 담낭적세순, 넙
Table 7. Comparison of pathologic findings Group 1 and Group 2

\begin{tabular}{lcc}
\hline Pathologic findings & Group 1 & Group 2 \\
\hline Cell type (cases) & & \\
Adenocarcinoma & 17 & 30 \\
Undifferentiated & 2 & 7 \\
Differentiation & & \\
Well & 3 & 1 \\
Moderate & $13^{*}$ & 1 \\
Poor & 3 & $28^{*}$ \\
\hline$: p<0.05$ & &
\end{tabular}

프절 곽청술, 설상간 전제술을 시행하였으며 고식적 수 술로 담낭절세술 및 $\mathrm{T}$-관 백액술을 4 예, 총담도공상 문한술을 9예에서 시행하였고 5 예에서는 적제가 불가눙 하여 조식생검만 시행하였다.

수술방법에 있어서 체 I 곤은 근치적 절세술을 시행한 경우가, 제 2 군은 기식적 수술을 시행한 경우가 빦아 양 곤간에 유의한 차이롤 보였다(p<0.05, Table 6).

\section{7. 조직화적 소견}

제 l 난의 답낭 압의 욱안젓 소견은 둔훌형(protruding type)이 13예(68\%), 표세형 (superficial type)이 6예 $(32 \%)$ 였고, 세포 형배는 선암이 17 에 $(89.5 \%)$, 미본화 압이 2예였다. 분화노는 충능 노 분화(moderately differentiated)압이 13예(68.4\%)로 가장 밚았고 고한화 (Well-differentiated) 압이 3예(15.7\%), 저분화(poorly differentiated) 압이 3 예 $(15.7 \%)$ 였다. 답낭 압의 칩윤 ․:(depth of invasion) 는 T 난휴상 T1이 2 예 $(10.5 \%)$, T2가 5예(26.4\%), T3가 10예(52.6\%), T4가 2에 $(10.5 \%)$ 였다. 세 2 간의 남낭 암의 세포형은 선암이 30 예(81.1\%), 끼반화압이 7예(18.9\%)였고 분화도는 저 변화압이 28 예 (75.7\%), 충능 5 : 분화암이 8예(21.6\%) 고건화압이 1 예 $(2.7 \%$ )였다. 납낭접제 시행한 15 예

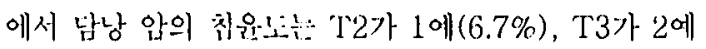
(13.3\%), ' T4가 12에(80.0\%)였다. 납낭 암의 분화년:

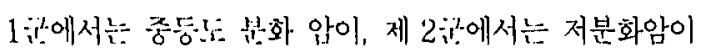

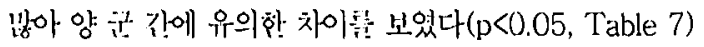

\section{고 찰}

원밖성 담낭 압은 낞은 의학적 밝전에도 불구하고 예 하가 분량한 악성 종양이나. 항히 고령에서 호발하며, 초

\section{dCollection @ ewha}


기에는 중상이 없거나 특징적인 임상 양상이 없어 조기 진단이 어렵고, 담낭의 해부학적 구조가 조기에 주변조 직으로 전이가 생겨 근치적인 절제술이 어럽기 때문에 예후가 불량하다 ${ }^{2) 4)}$. 여성에서 남성보다 3 4배 많이 발

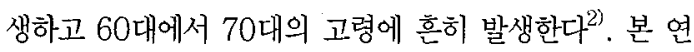
구에서는 대상 환자의 평균 연령이 $64 \pm 9$ 세였고 50 대 에서 60 대가 $52 \%$ 를 차지하였으며 여성에서 남성보다 2.3 배 많은 분포를 보였는데 평균 연령은 60 대이었으나 50 대에 발생빈도가 반 수 이상을 차지하여 발생 연령이 약간 젊어지는 경향으로 보였는데 실제로 병의 발생 연 령이 젊어진다기보다는 검사 방법의 발전과 검진이나 검 사의 중요성 인식이 높아진 것으로 해석된다.

담낭 암의 원인은 정확하게 밝혀져 있지 않으나 지역 적 또는 인종적 유병율의 차이롤 고려한 유전적 소인과 지방 섭취과다 등의 식생활 습관, 비만, 여성호르몬 등의 관여하고 담석증, 만성 담낭염, 양성 담낭 종양 등이 유 발인자로 알려져 있다. 특히, 담낭 암에서 담석이 동반 되는 빈도는 $73 \%$ 에서 $96 \%$ 정도이며 deoxycholic acid 에서 유래한 methyl cholanthrene이 발암성과 관런이 있는 것으로 보고되고 있다 ${ }^{7)}$. 본 연구의 경우 복부 초음 파검사에서 담낭 결석의 동반은 제 1 군에서는 $89 \%$, 제 2 군에서는 $50 \%$ 로 나타났다. 다른 보고에 비해 제 2 군 이 담석 동반이 적은 이유는 $54.1 \%$ 만이 수술을 시행하 여 담석의 동반 여부를 확인하였기 때문이고 나머지 환 자에서도 복부 초음과검사를 시행하였으나 종양의 음영 으로 인해 담석의 존재를 정확히 파악하기가 어려웠기 때문으로 생각한다.

담낭 암의 임상중상은 증상이 전혀 없거나 발열을 동 반한 우상복부 통증을 보이는 담낭염의 양상, 통증과 폐 쇄성 황달을 동반하는 경우, 또는 복통과 체중감소를 보 이는 경우 등이다. 환자의 $60 \%$ 정도는 종양이나 담석에 의한 페쇄로 인하여 급성 담낭염의 증상이 생긴다.”. 본 연구에서 제 1 군에서는 우상복부 동통과 오한 및 발열이 많았고 이병 기간도 짧아 급성 염증성 질환의 특성을 보 였다. 식옥부진, 전신 쇠약감, 체중감소, 황달이 동반된 경우도 있었으나 모두 고열과 통증을 동반하고 있었다. 제 2 군에서는 전신 쇠약감, 식욕부진, 체중감소 등의 만 성 소모성 질환의 증상이 많았고 우상복부 동통, 오한, 발열, 백혈구 수 증가 등의 염증성 특징을 보인 환자가 6 예(16.2\%)였다.
담낭 암의 진단으로는 주로 복부 초음파와 복부 전산 화단층촬영이 이용되며 최근에는 내시경 초음파점사의 발달로 병변 및 심달도를 평가하고 주위 조직으로의 침 윤, 국소 림프절 전이를 진단하는데 많은 정보를 얻을 수 있다. 복부 초음파검사는 악성종양을 선별 (screening) 할 수 있는 융ㅇㅇ한 검사이나 진단율은 44 88\%로 매우 다양하게 보고되며 방사선학적 검사의 발전에도 불구하 고 특징적인 진단기준이 정립되어 있지 못해 수술 전 담 낭암의 진단은 여전히 어렵달. 초음파검사에서 담낭 암 의 형태는 종괴형 (massive type), 벽비후형 (thickened wall type), 폴립형 (polypoid type)의 세 가지 유형으로 구분한다 ${ }^{10)}$. 벽비후형의 경우 국소적이며 불규칙한 벽 의 비후를 보일 때는 진단이 용이하나, 전반적이고 규칙 적인 벽비후를 보일 경우에는 비후 자체가 담낭 암의 특징적인 형태가 아니므로 다른 담낭 질환과의 감별이 매우 어렵다. 특히, 담석을 동반한 담낭염의 경우에는 담석으로 인한 후방그림자로 중양이 가려지거나 동반된 담낭염 때문에 진단에 어려움이 있다. 주변 간에 병변이 동반되거나 림프절종대 등의 부수적인 소견이 동반되면 감별진단에 도움이 되나 림프절 종대는 담낭염에도 관 찰되는 소견임으로 특징적인 소견이 아니다. 국내에서는 최 둥 ${ }^{11)}$ 과 박 등 ${ }^{12)}$ 이 담낭 암의 초음파적 진단의 오진 원인을 분석한 연구에서 전반적이거나 불규칙한 벽비후 형의 담낭 암이 담석을 동반한 경우에는 단순 담낭염과 감별이 제일 어렵다고 지적하였다. 또한 염증의 중상을 보이는 환자의 경우는 담낭염에 대한 선입견을 가지고 초음파 검사를 시행하게 되어 진단이 어렵고, 비특이적 인 임상증상을 보이는 경우 국소적인 벽비후나 담낭경 부에 위치한 병변을 간과하기 쉬워 진단의 어려움이 있 다고 분석하였다. 본 연구에서도 제 1 군에서 담낭결석이 $89.5 \%$ 에서 동반되었고 $4 \mathrm{~mm}$ 이상의 벽비후를 보인 9예 는 모두 미만성 벽비후의 형태를 보였다. 그 중 6예는 규칙적인 비후소견을, 3 예는 불규칙한 비후소견을 보였 으며 불규칙한 비후소견을 보인 3 예는 모두 담낭 농양 이 동반된 환자였고 2 예에서 림프절 종대 소견을 보였 다. 또한 발열과 우상복부 압통, 백혈구 증가의 소견을 보여 급성 담낭염으로 진단된 경우였다. 담도 확장이 있 던 3예는 간내외 담석이 동반되어 그에 따른 담도학장 으로 판단하였다.

담낭 암의 치료는 수술을 통한 종양의 완전 절제가 중

\section{dCollection @ ewha}


요하다. 그러나 $80 \%$ 가 진단 당시 이미 절제가 불가능하 고 근치적 절제롤 할 수 있는 경우는 10 30\%에 불과하 여 60 80\%는 진단 후 1 년 이내에 사망한다 ${ }^{13-15)}$. 담 낭 암은 담낭절제술 후 10 40\%에서, 전체 양성 간담도 질환의 수술 후 1 $2 \%$ 에서 -우연히 발견될 수 있다 ${ }^{16)}$. 국내 보고에서는 양성 담도질환으로 수술한 담당의 표 본 527 예 중 담낭 암이 $1.89 \%$ 를 차지하였다 ${ }^{17)}$. 그러 나 수술로 우연히 진단된 담낭 암은 대부분 낮은 병기 를 보여 근치적 절제가 가녕하며 대부분 점막과 고유근 층에 국한된 조기 암이 많아 예후가 비교적 양호하며 5 년 생존율은 $85 \%$ 이상이며 10 년 생촌율은 $16 \%$ 정도 로 보고되고 있어 이는 일반저ㅇㅣㅣㄴ 담낭 암의 5 년 생존율 인 1 5\%와는 비교할만한 결과이다 ${ }^{18-20)}$. 본 연구에서 도 제 1 군이 제 2 군에 비해 병기가 낮았고 근치적 절제 술은 $84.2 \%$ 에서 시행할 수 있었으나 제 2 군은 $10 \%$ 에 불과 하였다.

수술 방법은 담낭과 주위 조직의 완전 절세가 기본 원 칙이나 병기에 따라 다르고 수술 후 조직소견으로 진단 된 암의 치로에 대해서는 논란의 여지가 있다. 점막과 근 육 층에 국한된 담낭 암은 단순 담낭절제술만으로도 치 로가 간ㅎㅇ한 것으로 알려져 있으나 근육충에 국한된 암 이라도 새반올 줄이고 생존기간을 연장시키기 위해서는 설상간 절제술과 주위 림프절 곽청술을 포함하는 근치적 담낭절제술을 시행해야 한다는 주장도 있닥)(i). 제 III기 과 제 IV기에 대해서는 간 절체를 포함한 림프설 낙청술 이 필오하며 간상부 부반 구역절세 이상의 간 젋세, 남노 또는 췌두부 십이치상 전제 및 립프절 곽청술울 포함하 는 확대 절제술이 예후를 항상시킨다는 보고도 있다 ${ }^{17}$.

담낭 암 환자의 예후는 진단 시의 병기와 수술방법 닟 조직형에 따라 경정되며 점막과 고유 근충에 국한된 벙 변인 경우, 고번화 세쪼헝인 겅우에 림쪼절 및 간으로의

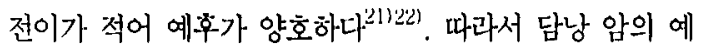
후를 항상시키기 위헤서는 조기 진단과 적극적인 수순치 료가 가장 중요하며 양성실환의 수술로 담낭울 설제하 는 경우에도 반드니 남낭 내외부론 욱안적으로 확인하 고 조직학적 확인이 중요하다. Mori 둥리은 담석이 동 반된 환자의 경우 담낭 암의 조기 진단을 위해서는 고령. 방사선학적으로 답낭에 $1 \mathrm{~cm}$ 이상의 폴립형 종괴가 난 찰된 경우, 또는 혈청 $\mathrm{CEA}$ 가 높은 경우에는 무충상의 담석이라도 담석과 폴립형의 종괴와 구별이 어려우모가. 적극적인 담낭절제와 병리학적 확인이 반드시 필요하다
고 주장하였다.

최근 양성 담도계 질환의 복강경적 수술이 보편화됨에 따라 우연히 진단된 악성 종양이 많아지게 되었다. 담낭 암의 경우 trocar 부의를 봉한 종양의 전이 문제와 수술 종로 후 진단되는 경우에 환자의 부가적인 치료와 추적 검사의 문제가 대두되고 있다. 외국의 보고에 의하면 복 강경적 담낭절제술 후 병리학적으로 담낭 암이 진단된 경우는 $2.85 \%$ 이며 이러한 경우 trocar 부위와 담낭 저 부, 주변 조직에는 수술 후 방사선 치료가 도움이 된다고 하였다 ${ }^{23)}$. 이러한 문제점올 극복하기 위해서는 수술 전 담낭 암의 소견이 의심된다면 복강경적 절제술을 피하는 것이 바람직하며 반드시 수술 충 담낭의 조직학적 검사. 를 시행하야 할 것이다.

본 연구에서는 양성 담도질환의 수술로 진단된 담낭 암 환자가 처음부터 담낭 암으로 진난한 군에 비해 담 낭 암의 병기가 낮았고 $84.2 \%$ 에서 근치적 전제술이 가 능하였다. 양성 담낭 질환의 주 중상을 가진 담낭 암은 수술 전에 진단하는 것은 매우 어려운 문제이다. 이러한 환자군은 암의 병기가 비표적 낮고 근치적 절체율이 높 으므로 이를 조기에 진단하튼 것히 중요하쟀다. 결로척 으로, 앙성 담도질환의 담낭 수술시 담낭 내외부의 세심 한 관찰과 조직학적 확인이 반드시 필요하며 양성 남낭 질한에서도 수술적인 치로가 필요한 경우라면 적득석으 로 수술울 고려해야 할 것으로 생각된다.

\section{요 약}

\section{목 적:}

원발성 담낭 암은 담도계 악성 종양 쑹 가장 현한 질 환으로 조기 진난이 어려워 예후가 불량하다. 양성 담 노실환의 수술로 우연히 진단된 남낭 압은 비교적 병기 가 낮아 에후가 양호한 것으로 보고되고 있으나 이에 대한 푼내 고찰은 매우 적은 실정이나. 본 연구에서는 양성 담너질환의 담낭절제술고 진단횐 남낭 암 환자둘 의 입상적 툭징과 방사선학적, 병리학적 특성을 분석하 고 처음부터 남낭 암으로 진단하! 겅우와 비교 분석하고 자 하였다.

\section{대상 및 방ㅂㅂㅂ :}

1993년 10월부터 1999년 3욜까지 이화여자대학교부 속복동병원에 입원하여 양성 담도십환의 수술로 진단된 남낭 압 환자 19 명가 $\left(1 i^{2}\right)$ 처음바터 방사선학적 소견과

\section{dCollection @ ewha}


조직병리 소견울 봉해 담낭 암으로 진단한 환자 37 명을 (2군) 대상으로 하였다. 대상 환자의 의무기록 분석을 통해 두 군의 임상 증상과 신체검진 소견, 검사실 소견, 방사선학적 소견, 담낭 암의 병기, 수술소견, 그리고 조 직병리학적 소견 등을 비교분석 하였다.

\section{별 과 :}

임상증상은 제 1 군에서는 우상복부 동통과 발열 및 오 한의 증세가 우세하여 급성 염증성질환의 특성을 보였 고 이병 기간도 짧았다. 제 2 군에서는 전신 쇠약감, 식욕 부진, 체중감소 등의 만성 소모성 질환의 증상이 우세하 였다. 복부 초음파검사는 1군에서는 담낭소견은 비특이 적인 소견을 보였으며 미만성 담낭 벽 비후가 $47.3 \%$ 에 서 관찰되었고 담석은 $89.5 \%$ 에서 동반되었다. 제 2 군은 모든 예에서 종괴나 불규칙한 담낭 벽 비후를 보였고 $50 \%$ 에서 담석이 동반되었다. 병기에 있어서는 제 1 군 에서는 I 기가 $10.5 \%, \Pi$ 기 $21.1 \%$, III기 $2.6 \%, \mathrm{IVb}$ 기 $15.8 \%$ 였고, 제 2군은 피기 $8.1 \%, \mathrm{Na}$ 기 $32.4 \%, \mathrm{IVb}$ 기 $59.5 \%$ 으로 제 1 군에 비해 훨씬 진행된 병기를 보였다. 수술은 제 1 군에서는 근치적 절제술을 16 예 (84.2\%)에 서 가능하였고, 제 2 군은 2 예 $(10 \%)$ 에서 시행하였다.

\section{결 론 :}

양성 담도질환의 담낭 절제술로 진단한 담낭암은 병기 가 비교적 낮고 근치적 절제술의 가능성이 높으므로, 담 낭 암을 조기에 진단하고 예후를 향상시키기 위해서는 양성 담도질환의 담낭 수술시 담낭 내외부의 세심한 관 찰과 조직학적 확인이 반드시 필요하다. 또한 양성 담낭 질환에서도 수술적인 치료가 필요한 경우라면 적극적으 로 수술을 고려해야 할 것으로 생각된다.

\section{References}

1) Nevin B : Gallbladder carcinoma. Am Oncol 1999 ; $10: 129-130$

2) Henson DE, Albores-Saavedra J, Corle D : Carcinoma of the gallbladder. Cancer $1992 ; 70: 1493-1497$

3) Nagormery DM, McPherson GAD : Carcinoma of the gallbladder and extrahepatic bile ducts. Semin Oncol $1998 ; 15: 106-109$

4) Muizumoto R, Ogura Y, Kusuda $T:$ Definition and diagnosis of early cancer of the biliary tract. Hepatogastroenterology $1993: 40: 67-77$

5) Bergdahl L : Gallbladder carcinoma first diagnosed at microscopic examination of gallbladders removed for presumed benign disease. Ann Surg $1980 ; 191$ : 19.22

6) Nevin JE, Moran TJ, Kay S : Carcinoma of the gallbladder staging, treatment and prognosis. Cancer 1976 ; $37: 141-148$

7) Olken SM, Bledsoe R, Newmark H III : Primary carcinoma of the gallbladder. Radiology $1978 ; 129$ : 481-482

8) Pandey M, Pathak AK, Gautam A, Aryya NC, Shukla $\mathrm{VK}$ : Carcinoma of the gallbladder : a retrospective review of 99 cases. Dig Dis Sci $2001 ; 46: 1145-1151$

9) Weifer SN, Koeingsberg M, Morehouse H: Sonography and computed tomography in the diagnosis of carcinoma of the gallbladder AJR $1984 ; 142: 735-738$

10) Yeh $\mathrm{H}$ : Ultrasonography and computed tomography of carcinoma of the gallbladder. Radiology $1979 ; 133$ : 167-173

11) 최병인 - 이진성 · 김승협 - 한만청 - 김주완 : 담낭암 에 있어서 초음파검사의 진단적 가치 : 전산화 단 층촬영술과의 비교. 대한초음파학회지 $1989 ; 8$ : 8-12

12) 박지현 · 문정미 · 안상원 · 송익훈 : 담낭암의 초음파 소견 : 오진된 예의 분석. 대한초음파학회지 1993 ; $12: 157-162$

13) D'Amico D, Bassi N, D'Erminio A : Current situation in the treatment of gallbladder cancer. Hepatogastroenterology $1991 ; 38: 16-21$

14) de Aretxabala X, Roa I, Burgos L, Araya JC, Fonseca L, Wistuba I, et al : Gallbladder cancer in Chile. Cancer $1992: 69 ; 60-69$

15) Hamrick RE, Liner FJ, Hastings PR, Cohn I : Primary carcinoma of the gallbladder. Cancer $1992 ; 70$ : 1493-1497

16) Shirai Y, Yoshida K, Tsukada K, Muto T : Inapparent carcinoma of the gallbaldder. An appraisal of a radical second operation after simple cholecystectomy. Ann Surg $1992 ; 215: 326-331$

17) Kwon SY, Chang HJ : A clinopathological study of unsuspected carcinoma of the gallbladder. JKMS 1997 ; $12: 519-522$

18) Piehler JM, Circhlow RW : Primary carcinoma of gallbaldder. Sufg Gynecol Obstet $1978 ; 147: 929-932$

19) Oertli D, Herzog U, Tondeli P : Primary carcinoma of the gallbaldder operative experience during a 16 year period. Eur J Surg $1993 ; 159: 415-420$

20) Piehler JM, Circhlow RW : Primary carcinoma of gall- 
bladder. Arch Surg $1977: 112: 26-29$

21) Hisatomi K, Haratake J, Horie A, Ohsato K : Relation of histopathological features to prognosis of gallbaldder cancer. Am J Gastroenterol $1990 ; 85: 567-572$

22) Pitt HA, Dooley WC, Yeo CJ, Cameron JL : Malignancies of the biliary tree. Curr Probl Surg 1995; 32 :
1.9

23) Mori T, Souda S, Hashimoto J, Yoshikawa Y, Ohshima $\mathrm{M}$ : Unsuspected gallbaldder cancer by laparasopic cholecystectomy : A clinicopathological study. Surg Today $1997: 27: 710-713$ 